
$\S 87$. Die Beförderung von Auswanderern
1. Einleitung. - 2. Der Geltungsbereich des deutschen Auswan- derungsgesetzes. - 3. Das Auswanderungsrecht anderer Staaten. - 4. Einwanderungsgesetze. - 5. Mehrfache Zuständigkeit. - 6. Amtshandlungen auBer Landes.

268

\title{
Abkūrzungen .
}

Journal = Journal du droit international (privé).

Revue - Revue de droit international privé.

Zeitschrift $=$ Zeitschrift für internationales Recht (für internationales Privatund Strafrecht, für internationales Privat- und öfientliches Recht).

Martens $=$ G. F. Martens, Nouveau recueil général de traités (Martens $^{2}=$ 2e série). 
